\title{
A re-evaluation of the palaeoclimatic significance of phosphorus variability in speleothems revealed by high-resolution synchrotron micro XRF mapping
}

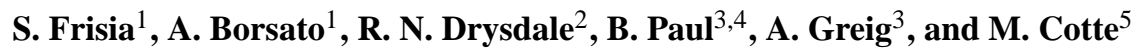 \\ ${ }^{1}$ School of Environmental and Life Sciences, University of Newcastle, Callaghan 2308 NSW, Australia \\ ${ }^{2}$ Department of Resource Management and Geography, The University of Melbourne, Parkville 3010 Victoria, Australia \\ ${ }^{3}$ School of Earth Sciences, The University of Melbourne, 3010 Australia \\ ${ }^{4}$ CODES ARC Centre of Excellence in Ore Deposits and School of Earth Sciences, University of Tasmania, Australia \\ ${ }^{5}$ European Synchrotron Radiation Facility, 38043, Grenoble Cedex, France
}

Correspondence to: S. Frisia (silvia.frisia@ newcastle.edu.au)

Received: 16 June 2012 - Published in Clim. Past Discuss.: 11 July 2012

Revised: 22 November 2012 - Accepted: 22 November 2012 - Published: 14 December 2012

\begin{abstract}
Phosphorus (P) is potentially a very important environmental proxy in speleothem palaeoclimate reconstructions. However, the transfer of $\mathrm{P}$ to a speleothem seems to vary between cave sites. Therefore, it is important to investigate the source of $\mathrm{P}$ and the way it is incorporated into a speleothem on a site-by-site basis before it can be used as a robust palaeoclimate proxy.

In this paper, the distribution of $\mathrm{P}$ in one modern and two Early Pliocene speleothems formed in coastal caves on Christmas Island (Indian Ocean) and the Nullarbor Plain (southern Australia) is investigated using microscopy and ultra-high resolution chemical mapping.

Phosphorus has been found to be both incorporated in the lattice and present as diverse P-rich phases. Monitoring data from Christmas Island suggest that co-precipitation of P-rich phases occurs when 'prior calcite precipitation' decreases following recharge, even if the drip rate decreases. Microbial mediation may also play a role, which complicates a direct climate relationship between $\mathrm{P}$ and hydrology. We find that some P-enriched layers contain dissolution features, with possible involvement of microbial mats which colonise pores during reduced drip rates associated with prolonged dry spells.

In the two Early Pliocene speleothems the relationship between $\mathrm{P}$ and microbial laminae is clearer. Both petrographic and chemical data suggest that phosphorus-rich phases in the microbial laminae mark intervals of reduced drip rates, which
\end{abstract}

may indicate dry intervals during the otherwise wet palaeoclimate of the Early Pliocene.

We develop a speleothem distribution coefficient for phosphorus $\left(\mathrm{SK}_{\mathrm{P}}\right)$ rather than the thermodynamic partition coefficient $\left(\mathrm{K}_{\mathrm{P}}\right)$ to account for the presence of crystalline phosphate inclusions. $\mathrm{SK}_{\mathrm{P}}$ describes $\mathrm{P}$ enrichment in speleothems regardless of the process, as similar mechanisms of phosphate co-precipitation may be in operation in biotic and abiotic conditions.

The most important implication of our study is that variability in $\mathrm{P}$ concentration may be related to diverse processes which can be recognized through petrographic observations and chemical mapping. In particular, there may not be a direct relation between an increase in $\mathrm{P}$ concentration and seasonal infiltration as has been found in some previous studies, especially if the source of this element is not the labile phosphate released through leaching during seasonal vegetation dieback in temperate climates.

\section{Introduction}

Much current speleothem-based palaeoclimate research capitalizes on models and experiments of stable isotope fractionation under a wide spectrum of environmental parameters (Hendy, 1971; Romanek et al., 1992; Scholz et al., 2009; Tremaine et al., 2011; Dreybrodt and Scholz, 2011). 
By contrast, similar studies involving trace element incorporation in speleothems has only recently gained momentum, even though trace element data has long provided robustness to palaeoclimate and ecosystem process reconstructions (e.g. Hellstrom and McCulloch, 2000; Borsato et al., 2007; Griffiths et al., 2010; Lewis et al., 2011). The incorporation of trace elements in cave calcite is related to the composition of the parent fluid (cf. Fairchild and Baker, 2012), crystal-surface processes and complex interactions between crystal surfaces and microbes (Banfield and Nealson, 1997). The latter is the most controversial (cf. Jones, 2010a) because bacteria may drive non-equilibrium partitioning (Warren et al., 2001).

Direct and indirect evidence of microbial influence on calcite precipitation has been frequently documented (Cañaveras et al., 1999; Castanier et al., 2000; Jones, 2001; Braissant et al., 2003; Cacchio et al., 2004; Barton and Northrup, 2007) to the point that the assumption that speleothem calcite forms through pure abiogenic processes has been challenged (Jones, 2009, 2010a, b). Stromatolite morphologies typical of calcite precipitation associated with bacterial action, such as filaments, rods and layered micrite, have been reported in flowstones and stalagmites from caves in the Italian Alps (Borsato et al., 2000; Frisia and Borsato, 2010), and organic compounds extracted from the same speleothems have been related to bacteria (Blyth and Frisia, 2008). Whether the microbes are transported from the soil or inhabit the speleothem in situ remains unclear. Cave-dwelling chemolithotrophs, however, were inferred to be responsible for the formation of fossil stromatolites in the deep, dark interior of a cave in Spain (Rossi et al., 2010). Still, despite growing evidence, biomediation has been largely neglected in speleothem-based palaeoclimate research because its products "have chemical properties within the range of laboratory precipitated inorganic crystals" (Fairchild and Baker, 2012). Controversy has recently focused on the palaeoclimatic significance of phosphorus $(\mathrm{P})$ concentration variability in speleothems.

A study on $\mathrm{P}$ variability in a modern speleothem from Western Australia suggested a link between increases in rainfall and increases in the speleothem $\mathrm{P} / \mathrm{Ca}$ ratio (Treble et al., 2003). P concentration maps generated by Synchrotron Radiation-based micro X-Ray Fluorescence (SR- $\mu \mathrm{XRF}$ ) of annually layered speleothems from the Alps also revealed a connection between higher infiltration and $\mathrm{P}$ peaks (Borsato et al., 2007). The P/Ca ratio in stalagmites, thus, has become a proxy for seasonal hydrological variability and ecosystem processes (Lewis et al., 2011). Nuclear Magnetic Resonance, however, reveals that $\mathrm{P}$ is not only present as adsorbed phosphate incorporated into the calcite lattice, but also as crystalline phosphate phases co-precipitated with the calcite (Mason et al., 2007). Critically, P peaks in Alpine speleothems were also associated with UV-fluorescent layers, where fluorescence is commonly activated by organic molecules (cf. Borsato et al., 2007). There was, thus, a po- tential relation between bacteria and P-rich phases, which became a subject of controversy when Jones (2009) concluded that caution should be exercised when considering the use of speleothem $\mathrm{P} / \mathrm{Ca}$ ratio as palaeoclimate proxy. The argument is based on observation of microbes and P-rich phases in speleothems from the Grand Cayman (Caribbean), where high concentration of $\mathrm{P}$ was interpreted to be the result of microbially related processes. The P-rich crystalline phases were observed to form in condensation-corrosion microcavities occupied by microbial mats, and mark periods when active calcite growth apparently stopped (Jones, 2009). In an extensive summary of speleothem research, Fairchild and Baker (2012) seem to dismiss the Grand Cayman microbial hypothesis, and advocate the common interpretation that increased $\mathrm{P} / \mathrm{Ca}$ ratio in stalagmites is a proxy for high rates of infiltration. The controversy, however, highlights a lack of knowledge regarding $\mathrm{P}$ in speleothems and its palaeoclimatic significance. To a certain degree, part of the problem is the avoidance of microscopy, based on the tacit assumption that such a method is useful only to discern recrystallization phenomena. Petrographic observation, however, should allow recognition of bacterially related morphologies. Another critical issue is the selection of the analytical methods, which understandably favours time- and cost-efficient Laser Ablation Inductively Coupled Plasma Mass Spectrometry (LA-ICP-MS). Climatically important trace elements such as strontium, phosphorus and silicon may form distinct coprecipitated phases or be associated with micro-detrital inclusions, all of which are potentially averaged in LA-ICP-MS analyses, which may encompass areas up to a few hundred square microns. By contrast, microfluorescence mapping allows resolution of element concentrations at the scale of 1 to $2 \mu \mathrm{m}$, which can be easily related to fabrics, and can potentially be used to determine whether tracers are in lattice or extra-lattice sites.

Here, we focus on the palaeoclimatic significance of $P$ by using a combination of techniques, from standard petrographic observations to LA-ICP-MS and SR- $\mu$ XRF mapping. We selected a modern speleothem from a low lying, island cave, not dissimilar to Grand Cayman, to elucidate mechanisms of $\mathrm{P}$ incorporation into speleothems growing in warm and wet coastal settings, and then used the reconstructed processes of phosphorus co-precipitation to investigate $\mathrm{P}$ in two speleothems formed in a cave near the southern Australian coast. Our study confirms that $\mathrm{P}$ concentration variability is a powerful climate proxy, but in our speleothems $\mathrm{P}$ peaks appear not to be related to an increase in colloidal transport from the soil, but to complex interactions between hydrological and microbial processes.

\subsection{Speleothems climatic and geologic settings}

The studied speleothems come from Smiths Cave at Christmas Island in the Indian Ocean $\left(105^{\circ} 40^{\prime} \mathrm{E}\right.$ and $\left.10^{\circ} 30^{\prime} \mathrm{S}\right)$ and Cave 645 (Winbirra) in the Nullarbor Plain in southern 


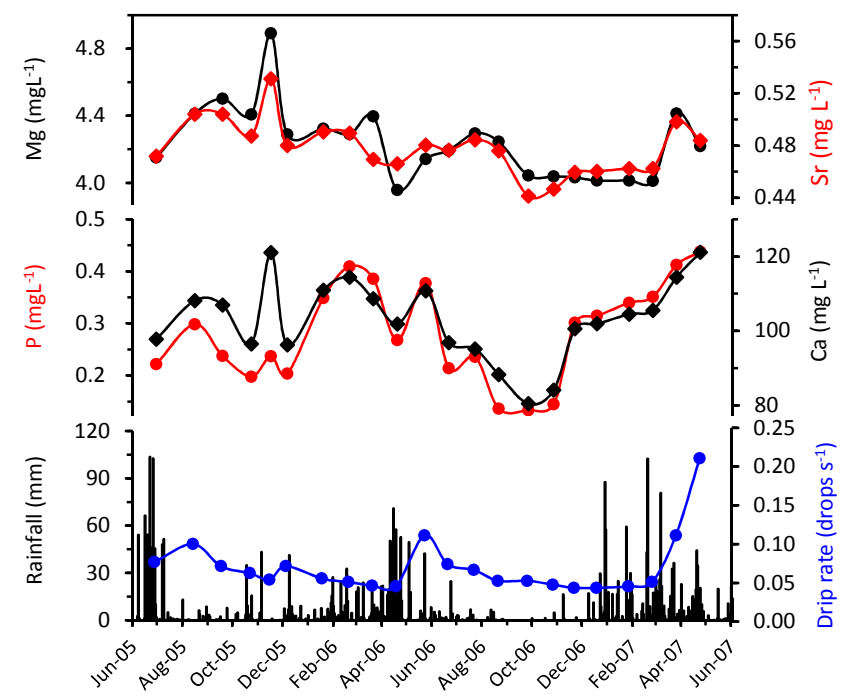

Fig. 1. Elemental (Mg, Sr, $\mathrm{P}, \mathrm{Ca})$ time-series for drip water feeding SC4 stalagmite, Smiths Cave, Christmas Island correlated with drip rates and rainfall data.

Australia (at ca. $128^{\circ} 30^{\prime} \mathrm{E}$ and $31^{\circ} 42^{\prime} \mathrm{S}$ ), and were originally collected for palaeoclimate studies. At Smiths Cave, the Cainozoic carbonate rock is a brecciated limestone which contains phosphatised volcanic rocks and phosphatic pebbles (Trueman, 1965; Grimes, 2001). The limestone is a rudstone-packstone with abundant coralline algae, fragments of coral and foraminifers cemented by isopachous, marine radial-fibrous cements. Original aragonite and $\mathrm{Mg}$-calcite are still partially preserved as revealed by X-ray diffraction. The phosphates mostly consist of carbonate hydroxyapatite. The two host rocks, thus, contain phosphate in different phases, which is typical of most Cainozoic shallow marine carbonates of the Indo-Pacific region (Ayliffe et al., 1992).

An actively forming stalagmite (SC4) was collected in 2004 from the coastal Smiths Cave, located on the NW part of Christmas Island, as part of a study of recent monsoon history. The temperature on the island is remarkably constant throughout the year ranging from $24^{\circ} \mathrm{C}$ in June-August to $26^{\circ} \mathrm{C}$ from December to March, whereas the mean annual rainfall is $(2100 \pm 725 \mathrm{~mm}$ recorded at Christmas Island Airport station from 1973 to 2011) has a marked seasonal distribution. During the wet season, from December to May, the NW monsoon results in mean monthly rainfall amounts between 215 and $350 \mathrm{~mm}$. The driest months on average are August to October, with mean monthly values of $42-67 \mathrm{~mm}$ (Fig. 1). However, the seasonal rainfall pattern evident in the mean monthly data masks significant year-to-year variability, with coefficients of variation ranging between $60 \%$ for January to $174 \%$ for September.

Initial attempts to date $\mathrm{SC} 4$ by uranium-thorium methods were unsuccessful due to several age reversals, presumably related to two contrasting sources of non-authigenic thorium, one of which is highly radiogenic (Hua et al., 2012). A robust age model was recently developed based on radiocarbon dating. Growth commenced ca. 600-700 yr ago with an almost linear growth rate of $\sim 0.3 \mathrm{~mm} \mathrm{yr}^{-1}$ (Hua et al., 2012). One feature revealed by exploratory LA-ICP-MS trace element analyses of SC4 is its high P concentration, which in the upper part of the stalagmite varies between 4000 and $8000 \mathrm{ppm}$ (Redwood et al., 2007). These concentrations are the highest reported to date in stalagmites, and are likely related to the presence of phosphates in the host rock. Petrographic observations and chemical mapping were focused on the regions where the highest $\mathrm{P}$ peaks were documented in the $\mathrm{P}$ cycles to unravel the possible mechanisms of such unprecedented $\mathrm{P}$ incorporation in a stalagmite. The synchrotron sample was cut from the top $30 \mathrm{~mm}$ and encompasses the last circa $100 \mathrm{yr}$ (the model age at $30 \mathrm{~mm}$ is $1894 \mathrm{AD}$ based on Hua et al., 2012).

The Miocene Nullarbor limestone observed from drilled cores and cave outcrops is a rudstone to grainstone/packstone with abundant coralline algae, benthic foraminifera, bryozoans and echinoid fragments cemented by microsparite and sparite, whose diagenesis occurred largely in the meteoric environment (cf. Miller et al., 2012). In the core samples, patches of carbonate hydroxyapatite and faggite occur, mostly as small void-filling cements. Phosphorus is also dispersed within bioclasts in concentrations ranging from 20 to $50 \mathrm{ppm}$ (LA-ICP-MS analyses, this work). Speleothems 645-FS04 and 645-MO1 were collected within the framework of a study on Pliocene climate in Australia (Woodhead et al., 2006) and have ages of 4.3 and 3.9 Myr respectively (Woodhead, preliminary $\mathrm{U} / \mathrm{Pb}$ data). Cave 645 (Winbirra) is located $20 \mathrm{~km}$ from the coast in the Nullarbor Plain (SW Australia) where, today, the only forming speleothems mostly consist of evaporites. The climate in the region is subtropical arid, characterized by seasonal rainfall (Bureau of Meteorology classification). Surface mean annual temperature is $17.2^{\circ} \mathrm{C}$, with a mean maximum temperature of $25.9^{\circ} \mathrm{C}$ in January and a mean minimum temperature of $7{ }^{\circ} \mathrm{C}$ in July recorded at the near-coastal station of Eucla (1926 to 2012). Mean annual rainfall recorded at the same station is ca. $270 \mathrm{~mm} \mathrm{yr}^{-1}$ (Bureau of Meteorology, statistics from 1876 to 2012). Today, the large annual hydrological deficit leads to a strong modification of the infiltration waters as indicated by chemical data for present-day drip and pool waters (Ca 200 to $700 \mathrm{mg} \mathrm{L}^{-1} ; \mathrm{Mg} 250$ to $750 \mathrm{mg} \mathrm{L}^{-1}$; $\mathrm{Na} 2800$ to $7000 \mathrm{mg} \mathrm{L}^{-1} ; \mathrm{Cl} 3500$ to $10000 \mathrm{mg} \mathrm{L}^{-1}$; from Turin and Webb, 2002). These waters are unlikely to be representative of drip waters in the Early Pliocene, when a climate wetter than today allowed extensive calcite speleothem formation. It is also plausible that during the Pliocene a more humid climate supported a greater coverage of C3-dominant vegetation (cf. Miller et al., 2012).

The two speleothems selected for this study, 645-FS04 and 645-MO1 are characterized by fabrics which are typical of Pliocene stalagmites and flowstones collected from different caves in the Nullarbor Plain (cf. Miller et al., 2012). The 
most typical fabric consists of compact translucent elongated columnar calcite, dark brown to honey coloured with visible laminations. Crystals show fascicular optic extinction and are composed of $\mathrm{Mg}$-rich calcite (up to 9 mole $\% \mathrm{MgCO}_{3}$ ). Changes in speleothem morphology (such as a diminution or increase in diameter, or shift in growth axis), are commonly marked by mm-thick, light coloured, opaque, microsparite layers showing irregular, microbial-like lamination. At least 6 of these layers are present in both the ca. $10 \mathrm{~cm}$ long 645FS04 and 645-MO1 speleothems. Similar layers have also been observed in other specimens from two caves near Winbirra. Preliminary trace element analyses revealed $\mathrm{P}$ peaks associated with the opaque layers. The similarity of the Winbirra speleothems P-enriched layers to microbial laminites, as well as the coastal location of the cave, suggest that the mechanisms of $\mathrm{P}$ concentration may have been similar to those acting at Great Cayman. The P-mapping on the Nullarbor speleothems was thus focused on the microbial laminite layers, which likely marked growth interruptions, as suggested in other settings (Frisia and Borsato, 2010) with the goal to find analogies (or discrepancies) with SC4 stalagmite and expand our limited knowledge on mechanisms of $\mathrm{P}$ incorporation in speleothems. Furthermore, analogies between the physical and chemical characteristics of the Cainozoic host rocks at Christmas Island and the Nullarbor, in particular the well preserved porosity and the presence of $\mathrm{P}$ phases, implies that the karst carbonates may play an important role in the complex system, which ultimately results in the incorporation in stalagmites of a key palaeoclimate proxy.

\section{Methods}

All samples had been analysed prior to this study for stable carbon and oxygen isotope ratios, and data for drip water chemistry and drip rate are available for Smiths cave. For the Nullarbor, the general absence of infiltration prevented a monitoring program. Petrographic observations were carried out on thin sections using optical microscopy. The micromorphological characteristics of crystals were investigated by Scanning Electron Microscopy (SEM). Rapid, in situ qualitative composition was carried out during SEM observations using EDAX mapping. Mineral phases were identified by Xray diffraction on both powdered (to avoid the effects of preferential fabric orientation) and polished samples, with acquisition time up to $10 \mathrm{~h}$. When necessary, micro-Raman spectroscopy phase recognition was carried out on the polished samples used for synchrotron mapping. Micrometer-scale trace-element distributions were mapped on polished, freestanding thick sections, using synchrotron-radiation micro $\mathrm{X}$-ray fluorescence (SR $\mu \mathrm{XRF})$ at beamline ID21 of the European Synchrotron Radiation Facility (ESRF). Instrumental settings and procedures were as described in Frisia et al. (2005) and Borsato et al. (2007). Polished thick sections, ca. $20 \mathrm{~mm}$ long, were ultrasonically cleaned, washed with deionised water, air-dried and handled with sterile gloves to avoid contamination prior to insertion in the sample chamber. Trace element concentrations were obtained as counts (cts). Quantitative concentrations of trace elements were then obtained on the synchrotron samples by LA-ICP-MS and calibrated using the NIST SRM612 glass reference material and the stoichiometric abundance of $\mathrm{Ca}$ in calcium carbonate. Samples were pre-ablated and a laser spot size of $71 \mu \mathrm{m}$ was used. Instrumental drift was monitored using the ${ }^{43} \mathrm{Ca}$ channel. Raw mass spectrometry data were reduced using the software Iolite (Paton et al., 2011) at the School of Earth Sciences, the University of Melbourne. Drip waters at Smiths Cave were collected in acid-washed, deionised water-rinsed glass vials from the stalactite-feeding SC4 at mostly monthly intervals (from July 2005 to April 2007) and analysed using a Varian Quadrupole ICP-MS at the University of Melbourne. Drip counts were taken using a stopwatch during each of the cave visits.

\section{P incorporation in speleothems and the partition coefficient concept}

Experimental studies on P-ion incorporation in calcite carried out by Ishigawa and Ichikuni (1981) at $20^{\circ} \mathrm{C}$ from solution compositions ranging from 1 to $120 \mathrm{mg} \mathrm{L}^{-1} \mathrm{Ca}^{2+}$ and 0.2 to $2.4 \mathrm{mg} \mathrm{L}^{-1} \mathrm{PO}_{4}^{3-}$ allowed them to calculate the partition coefficient $K_{\mathrm{P}}$, which was found to increase exponentially as a function of the $\mathrm{Ca}^{2+}$ content in solution (Fig. S1):

$K_{\mathrm{P}}=0.0025 \mathrm{Ca}^{1.6118}\left(r^{2}=0.98\right)$

Calcite precipitation modelling (Stoll et al., 2012) further indicates that the ratio between $\mathrm{HPO}_{4}^{2-}$ and $\mathrm{CO}_{3}^{2-}$ in the solution is inversely correlated to the $\mathrm{pH}$, and eventually to the $\mathrm{Ca}^{2+}$ concentration in the residual water. Critically, the products of the experiments of Ishigawa and Ichikuni (1981) were not tested for the presence of phosphates co-precipitated with calcite, which may be a common occurrence in speleothems (cf. Mason et al., 2007).

To date, investigation on the mechanisms of $\mathrm{P}$ incorporation in speleothem calcite is limited to examples from Grotta di Ernesto. P concentrations in the stalagmites from this cave located within an Alpine, temperate setting vary from 10 to $250 \mathrm{ppm}$ (Huang et al., 2001; Fairchild et al, 2001, 2010; Borsato et al., 2007). If we calculate the thermodynamic partition coefficient for $P$ for Grotta di Ernesto stalagmites, where $\mathrm{P}$ concentration of the topmost calcite layer is $\sim 85 \mathrm{ppm}$, drip water $\mathrm{Ca}^{2+}$ is $\sim 55 \mathrm{mg} \mathrm{L}^{-1}$, and drip water $\mathrm{P}$ is $\sim 3.5 \mu \mathrm{g} \mathrm{L}{ }^{-1}$ (Huang et al., 2001; Fairchild et al., 2001; Borsato et al., 2007), we obtain a $K_{\mathrm{P}}$ of 3.4 , which is two times higher than the theoretical value from Eq. (1) (Fig. S1). This discrepancy is explained by the different mechanisms of $\mathrm{P}$ incorporation: as orthophosphate ions in the calcite lattice, and through enclosure of calcium phosphate surface 
precipitates within the speleothem (Mason et al., 2007). The second process is related to the desorption of orthophosphate, which is colloidally transported during infiltration events at the end of the warm season (Borsato et al., 2007; Miorandi et al., 2010; Harland et al., 2012).

The fact that phosphorus is both incorporated as individual phosphate ions in the calcite lattice and forms phosphate co-precipitates (Mason et al., 2007) undermines the concept of thermodynamic partition coefficient as pointed out by Fairchild and Baker (2012). A new concept of a speleothem distribution coefficient for phosphorus $\left(\mathrm{SK}_{\mathrm{P}}\right)$ is required. Theoretically, the $\mathrm{SK}_{\mathrm{P}}$ should always be equal to or higher than $K_{\mathrm{P}}$ as it accounts for the presence of coprecipitation phases, regardless to the mechanisms of incorporation.

For all karst waters with a Ca concentration $>50 \mathrm{mg} \mathrm{L}^{-1}$, both $K_{\mathrm{P}}$ and $\mathrm{SK}_{\mathrm{P}}$ are $>1$. This means that during the precipitation of mineral phases the ratio $\mathrm{P} / \mathrm{Ca}$ will increase in the residual solution. Thus, if calcite and, possibly, P-rich phases co-precipitate en route to the stalagmite, $\mathrm{P}$ is scavenged from the waters, and the total concentration at the stalagmite top will be depleted relative to the original solution. This phenomenon was documented in stalagmite PN26 from Père Noël cave (Belgium), where the very low $\mathrm{P}$ concentrations (from $<0.2$ to $10 \mathrm{ppm}$ ) were interpreted to be the consequence of strong prior calcite precipitation (PCP), which removed nearly all P from the solution (Huang et al., 2001). The $S_{P}$ and PCP concepts will be applied in the following sections to interpret the chemistry of the drip water and the stalagmite for Smiths Cave.

\section{Variations in drip water $P$ concentration at Smiths Cave}

Drip waters feeding SC4 from 2005 to 2007 show the following mean values $( \pm 1 \mathrm{SD})$ for a suite of elements which are most commonly used for speleothem palaeoclimate reconstructions: Ca: $103 \pm 10.8 \mathrm{mg} \mathrm{L}^{-1}$; Mg: $\quad 4.24 \pm 0.22 \mathrm{mg} \mathrm{L} ; \quad$ P: $\quad 0.28 \pm 0.09 \mathrm{mg} \mathrm{L}^{-1} ; \quad \mathrm{Sr}$ : $0.48 \pm 0.02 \mathrm{mg} \mathrm{L}^{-1} ; \quad$ Ba: $2.13 \pm 0.34 \mu \mathrm{g} \mathrm{L}^{-1}$ (Fig. 1). There is a strong positive correlation between $\mathrm{P}$ and $\mathrm{Ca}$ $\left(r^{2}=0.84\right)$ with an intercept for $\mathrm{P}$ of $-0.6 \mathrm{mg} \mathrm{L}^{-1}$ (Fig. S2). This suggests that water/rock interaction (WRI) is not the major process controlling $\mathrm{P}$ variability in drip water, because if we assume a common source in the soil zone and aquifer for $\mathrm{P}$ and $\mathrm{Ca}$, WRI should result in a correlation line with an intercept around 0 (slope 1:1). Given that the $\mathrm{Ca}^{2+}$ concentration in the drip water is always $>80 \mathrm{mg} \mathrm{L}^{-1}$ (and $\mathrm{SK}_{\mathrm{P}}>1$ as discussed in above), the controlling mechanism is more likely the removal of $\mathrm{P}$ by co-precipitation of phosphate with calcite en route (PCP), which would preferentially deplete $\mathrm{P}$ in the residual solution.

The comparison between $\mathrm{Ca}$ and $\mathrm{P}$ concentration, drip rate and rainfall amount (Fig. 1) highlights that periods characterized by low $\mathrm{Ca}$ and $\mathrm{P}$ values (high PCP), namely Novem- ber 2005 to January 2006 and, to a lesser extent, September to November 2006, correspond to the periods with lowest rainfall amount and to a general decrease in drip rate. Because the mean monthly temperature at Christmas Island is constant throughout the year (and therefore constant potential evapotranspiration during the year), it stands to reason that there should be a linear relationship between rainfall and infiltration. There is, thus, a relation between infiltration and $\mathrm{P}$ concentration, although there is no direct relationship between $\mathrm{P}$ concentration and drip rate, which is probably governed by local storage and recharge effects resulting in periods when a decrease in drip rate coincides with an increase in $\mathrm{P}$ concentration (Fig. 1).

We can therefore assume that the P concentration in drip water feeding SC4 is mainly controlled by the effective infiltration. During specific transient infiltration episodes, however, piston effects and WRI can also play a role and the result is an overall increase in the concentration of dissolved $\mathrm{Ca}$ and $\mathrm{P}$ at the end of a dry period (November 2005 and AprilMay 2007 in Fig. 1). These episodes are clearly recorded also in the $\mathrm{Mg}$ and $\mathrm{Sr}$ concentration that otherwise display fairly constant values (Fig. 1). This observation leads to the issue of the source of $P$ in the drip waters.

Studies of temperate, boreal ecosystems indicate that the principal source of cave drip water $\mathrm{P}$ is leaching from plant residues during vegetation dieback, when this element is not taken up by plant roots and is retained in the soil zone (Filippelli, 2002; S $\varnothing$ et al., 2011; Fairchild and Baker, 2012). This process was assumed to be the source of $\mathrm{P}$ incorporated in stalagmites from southeastern Australia, where both temperature and rainfall show seasonal variations (Treble et al., 2003). The release of phosphorus during vegetation dieback is plausible where climate is seasonal, but Christmas Island is in a tropical setting, with a typical tropical rainforest vegetation association, where dieback would occur following severe moisture stress. Large trees, however, have deep roots that allow them to resist not only through the dry season, but, according to studies conducted in northern Australian forests, even during severe droughts (Prior and Eamus, 2000). The P in Smiths Cave drips (and hence of $\mathrm{P}$ available to the speleothem) is more likely to be sourced from the dissolution of apatite-group minerals present in the epikarst and brecciated rock, possibly through the ability to dissolve recalcitrant phosphates of mycorrhizal fungi (Van Leerdam et al., 2001). This would explain the high dissolved $\mathrm{P}\left(0.4 \mathrm{mg} \mathrm{L}^{-1}\right)$, which is 100 times higher than the dissolved $\mathrm{P}$ concentration in Grotta di Ernesto drip waters $\left(0.0035 \mathrm{mg} \mathrm{L}^{-1}\right.$ : Huang et al., 2001), believed to originate from seasonal leaching of the labile, organic forms of P (Borsato et al., 2007).

In summary, at Smiths cave, phosphorus in the drip water is most likely derived from the dissolution in the soil zone and epikarst of hydroxyapatite and chlorapatite, and its concentration variability is directly related to infiltration via PCP. Transient high P concentrations are associated with 


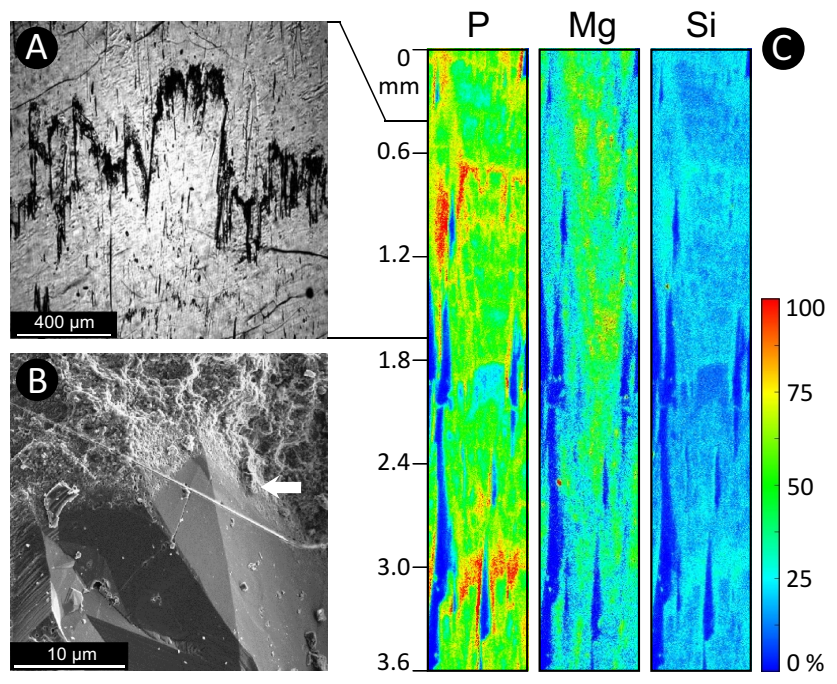

Fig. 2. Stalagmite SC4, Smiths Cave, Christmas Island. (A) Thin section showing one of two dark layers marking corroded crystal surfaces (polarised light). (B) Scanning electron microscope micrograph of the layer in (A). Note unaltered columnar crystals (bottom) and the corrosion surfaces, where P-rich phases are nested (shown in Fig. 3a-f). (C) Synchrotron radiation micro XRF maps $(600 \times 3600 \mu \mathrm{m}$, pixel size $6 \mu \mathrm{m})$ for $\mathrm{P}, \mathrm{Mg}$ and $\mathrm{Si}$. The maps were generated on the mirror, polished slab of the same specimen from which the thin section illustrated in (A) was taken. The correlation between thin section and synchrotron sample is highlighted by the tie lines. Concentration shown in temperature scale normalized to the minimum and maximum counts for each element: $\mathrm{P}=10$ to 185 cts; $\mathrm{Mg}=0$ to $60 \mathrm{cts} ; \mathrm{Si}=0$ to 195 cts.

prolonged water/rock interaction at the end of dry periods, whereas low $\mathrm{P}$ concentrations mark periods of $\mathrm{P}$ removal from the water through PCP.

\section{Phosphorus incorporation and its significance in SC4}

The SR $\mu$ XRF elemental mapping in the top part of SC4 reveals that the $\mathrm{P}$ concentration increases at discrete layers, which may or may be not visible in thin section, and around pores (Fig. 2a-c). Two distinctive layers stand out at 0.8 and $3.0 \mathrm{~mm}$ (Fig. 2c), where $P$ reaches a maximum concentration of ca. $8000 \mathrm{ppm}$, as determined by LA-ICP-MS. These two P-rich layers, 0.01 to $0.2 \mathrm{~mm}$ thick, correspond to highly corroded crystal surfaces marked by a dark coating visible in thin section (Fig. 2a-b). When viewed under the SEM, the dark coating appears to consist of tabular, lamellar and globular crystals nested in micrometre-sized hemispheric voids (Fig. 3a to d), lining crystal tips, where they are associated with fibers (Fig. 3e), and coating amorphous sheaths between crystals (Fig. 3f).

Preliminary Nuclear Magnetic Resonance (NMR) analyses suggest that these phases are similar to the unknown Prich phases reported by Mason et al. (2007) in annually lam- inated Alpine speleothems (B. Phillips, personal communication, 2010). These micrometre-sized P-rich phases show morphologies comparable to those observed in P-rich biogenic carbonates (Addadi et al., 2003) and to phosphates precipitated in the presence of proteins (Combes and Rey, 2002), but dissimilar to the morphologies associated with mineralization of actinomycetes illustrated by Jones (2009). The microcavities hosting P-rich phases in SC4, however, resemble the corrosion discontinuities colonized by microbes observed in the Caribbean speleothems, which were interpreted as the product of condensation-corrosion, or dissolution (Jones, 2009). In SC4, mixing corrosion due to seawater spray or influx of undersaturated drip water may explain the dissolution features, but the presence of amorphous sheaths lining microcavities (Fig. 3f), which are similar to exopolysaccharides, suggest that corrosion of crystal surfaces may have been mediated by biological oxidation processes (Frisia, 1996). The X-ray diffraction pattern did not match any known Ca-phosphates with the exception of ardealite, a phosphate typical of dry, slightly acidic environments, whose presence corroborates the hypothesis of dissolution being, at least in part, a by-product of organic matter oxidation.

The SR $\mu$ XRF maps (Fig. 2c) show that a minor fraction of P may also be incorporated in the solid lattice of the crystals similarly to $\mathrm{Mg}$, which is equally dispersed within the columnar calcite crystals, probably substituting $\mathrm{Ca}$ in the lattice. It is plausible that adsorption in thermodynamic equilibrium (that is, following the theoretical partitioning) as well as kinetic factors describe the processes leading to incorporation of $\mathrm{P}$ in $\mathrm{SC} 4$. The critical issue to be addressed, then, relates to the significance of the processes resulting in different patterns of phosphate co-precipitation within SC4. For the small $\mathrm{P}$ fraction that is incorporated in the calcite lattice, it is likely that near-equilibrium co-precipitation occurs when both $\mathrm{P}$ and $\mathrm{Ca}$ are low in the parent solution during periods of high PCP (dry seasons) (Fig. 1). The layers where distinct Prich phases form should, then, mark periods of high $\mathrm{P}$ and $\mathrm{Ca}$ in solution, when PCP is low and higher effective infiltration recharges the aquifer, with associated piston effects (Fig. 1).

The presence of features similar in appearance to microbial mats in the dark, P-rich layers characterized by corrosion features, however, complicates the hydrological significance of high P concentrations. By analogy with the conclusions reached by Jones (2009) for the Caribbean speleothems, these layers may actually mark periods of cessation of active calcite growth. The presence of ardealite indicates that the speleothem surface may have been dry at the time of its formation. Furthermore, SR $\mu$ XRF maps show the presence silicon ( $\mathrm{Si}$ ) on the corroded crystals (Fig. 2c). Higher $\mathrm{Si} / \mathrm{Ca}$ ratios in speleothems have been related to low rainfall (Polyak and Güven, 2000; Hu et al., 2005), but it is also known that bacteria may precipitate silica (Nash and Ullyott, 2007). It is, thus, plausible that bacterial mediation has a role in modulating P concentration in the dark, corroded layers. The metabolic activity of bacteria is extremely important in 

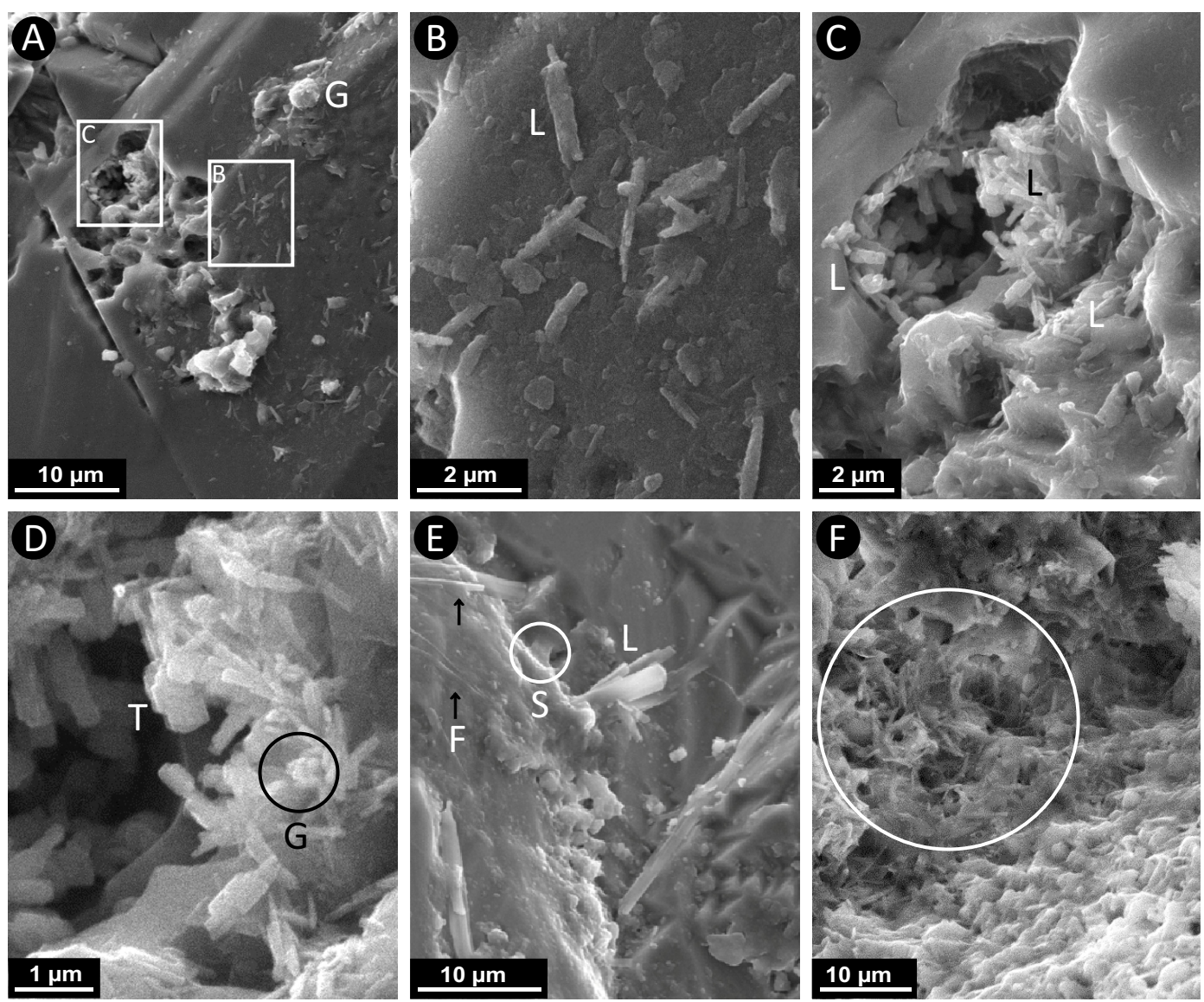

Fig. 3. Scanning electron microscope micrographs of the SC4 dark layer shown in Fig. 2a. (A) Overview of crystal surface with P-rich lamellae (box B is enlarged in B) and dissolution/corrosion voids where P-rich phases are nested (bow C is enlarged in C). G marks a large globular structure composed of lamellae. (B) Enlargement of the box B in Fig. 2a; $\mathrm{L}=$ lamellae. (C) Enlargement of box C in A; L = lamellae. The lamellae in the right hand corner of the figure precipitated onto a sheath which lined the cavities conferring a "smooth" appearance to the corroded surfaces. (D) Enlargement of C showing tabular crystals (T) and globular features (circle labelled G). (E) Mineralized filaments (F) embedded in calcite crystal (black arrows labelled F). $\mathrm{S}=$ sheath, $\mathrm{L}=$ lamellae. (F) Lamellae on a sheath lining dissolution/corrosion cavity.

supplying the necessary ions for the formation of phosphates and carbonates, and if $\mathrm{Ca}$ is consumed during precipitation of calcite, and additional $\mathrm{PO}_{4}^{3-}$ ions are released during organic matter degradation, phosphate minerals may potentially precipitate (cf. Sánchez-Román et al., 2007).

In conclusion, we suggest that in SC4 the phosphorus concentration variability is related to three different mechanisms of $\mathrm{P}$ incorporation, none of which marks seasonal vegetation decay, but rather hydrological processes within the aquifer controlled by the effective infiltration. Microbial processes may complicate the reconstructed hydrological significance: during relatively dry periods, when drip rate is very low (or even stops), calcite growth stops, microbial mats colonise the speleothem surface and crystal tips are corroded. When drips recommence, and piston effects enrich the waters with $\mathrm{P}$ and $\mathrm{Ca}$ (Fig. 1), both organic and inorganic processes may ultimately result in the formation of the dark, phosphaterich layers. The two distinctive layers at 0.8 and $3.0 \mathrm{~mm}$ can therefore be interpreted as the result of a longer-than-average dry season (corrosion-colonisation by microbes followed by infiltration). We believe that similar processes may occur in other tropical coastal caves characterised by the presence of phosphate in the host rock and a concentration of $\mathrm{Ca}$ in drip waters $>50 \mathrm{mg} \mathrm{L}^{-1}$.

The $\mathrm{SK}_{\mathrm{P}}$ calculated for SC4 by using the range of values for $\mathrm{P}$ and $\mathrm{Ca}$ concentration in the drip water, and the range of $P$ concentration in the stalagmite (from 4000 and $8000 \mathrm{ppm}$ ), varies from 4 to 8 , values which are within the range of, or slightly higher than, the theoretical $K_{\mathrm{P}}$ (Ishikawa and Ichikuni, 1981) (Fig. S1). Therefore, contrary to the conclusions of Jones (2009), the Smiths Cave data confirm the significance of $\mathrm{P}$ as a palaeohydrological proxy, and microbes may only slightly modify inorganic processes, as already suggested by Fairchild and Baker (2012). 


\section{The Nullarbor speleothems: hydrological significance of P-rich layers}

The understanding gained from the study of the mechanisms of $\mathrm{P}$ incorporation in SC4 can be used to interpret the significance of $\mathrm{P}$ concentration increases observed in stromatolitelike layers within the ca. 4 Myr-old stalagmites from Winbirra Cave. The dominant fabrics of 645- MO1 and 645FS04 (Fig. S3a and b) are interpreted as being formed under relatively constant drip rates and supersaturation (Frisia and Borsato, 2010). Contrary to SC4, the two Early Pliocene examples do not provide petrographic evidence of seasonal recharge variability. Rather, the compact columnar fabrics would imply formation under conditions of constant recharge (cf. Frisia et al., 2000). The internal stratigraphy, however, shows mm-thick white laminae, where several, stacked, irregular micrometre-scale micrite layers cap columnar crystals. The columnar calcite below the micrite shows evidence of dissolution (or corrosion), where pores had been subsequently filled by micrite and microsparite (Fig. S3c to f). The micrite layers are remarkably similar to those marking condensed deposition observed in Alpine stalagmites, whose formation was related to bacterial mediation (Frisia and Borsato, 2010). To date, the precipitation of micrite on the surface of stalagmites has no clear explanation. Nucleation and growth of abiotic micrite requires high supersaturation or the presence of a large number of pre-existing nuclei (or both). Even in seawater, which has a calcite saturation over 6 times that of present-day Winbirra waters (James, 1992), "inorganic" abiotic production of micrite appears to require nucleation on "old" sediment (Morse et al., 2003). In continental environments, micrite formation in laminar calcretes and tufas has a biotic component, such as precipitation mediated by cyanobacteria (Alonso-Zarza and Wright, 2010). It is therefore plausible that bacterial mediation was involved in the formation of the micrite layers observed in the Winbirra speleothems, which can be referred to as "stromatolite-like" laminae. A detrital origin of the micrite from the host rock is not supported by the fabric, and in particular by the observed dissolution of columnar calcite and its replacement by micrite (Fig. S3e-f).

The stromatolite-like laminae, which occur when the internal morphology of the speleothems changes, are characterized by distinctive $\mathrm{P}$ peaks as determined by LA-ICPMS (Fig. 4). In the stromatolite-like laminae of 645-FS04, marked as Phase 2 in Fig. 4, the concentration of $\mathrm{P}$ is 12 times higher relative to the baseline. The concentration of $\mathrm{Mg}$ in Phase 2 is within the mean values of Phases 1 and 3 (Figs. 4 and 5), whereas $\mathrm{Sr}$ and $\mathrm{Ba}$ concentrations are within the mean values for Phase 3, and the decrease in their concentration relative to Phase 1 occurs before the onset of Phase 2 (Fig. 4). A similar behaviour for $\mathrm{Mg}, \mathrm{Sr}$ and $\mathrm{Ba}$ has been interpreted as being sensitive to PCP (Treble et al., 2003), which would suggest that the stromatolite-like layer was preceded by a relatively dry episode, when the three divalent

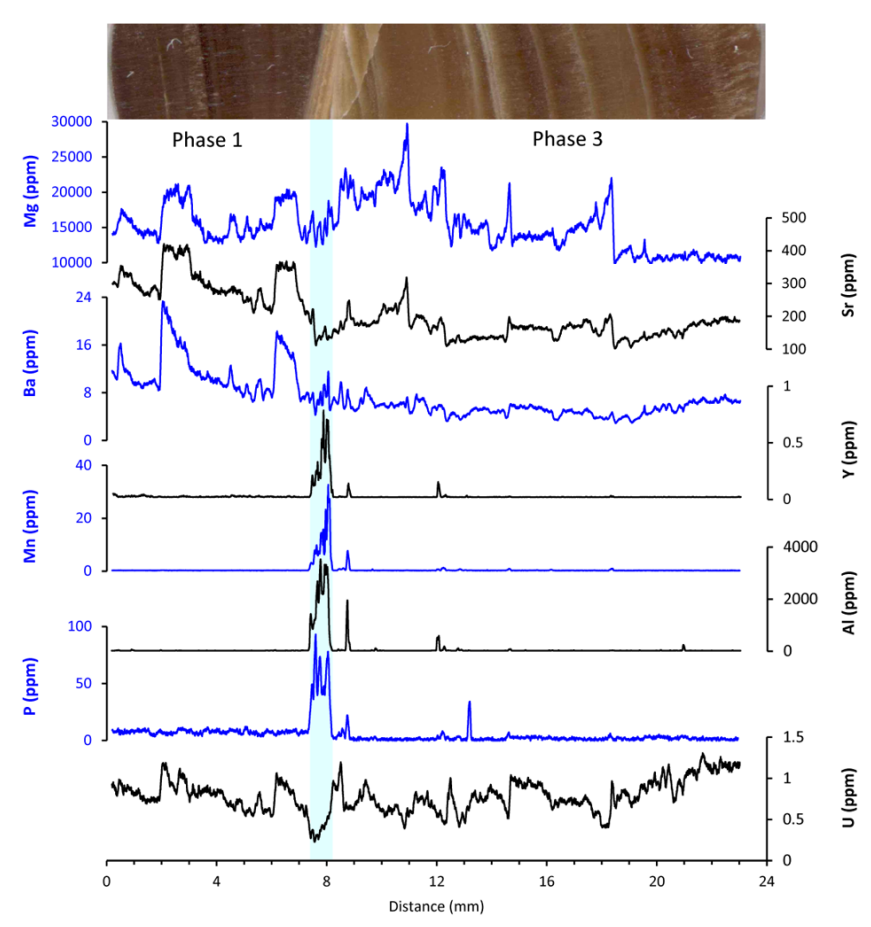

Fig. 4. Trace element variability across two elongated columnar calcite crystals (Phases 1 and 3 ) interrupted by a stromatolite-like layers (Phase 2) in speleothem 645-FS04 (Winbirra Cave, Nullarbor). The quantitative concentrations were obtained by LA-ICPMS. Growth direction of the speleothem is from left to right. All the elemental scans are averaged with a 15 points running mean corresponding to a width of $25 \mu \mathrm{m}$. The pale blue bar highlights the concentrations in the stromatolite-like layer (Phase 2).

cations peak, followed by recharge and then a period when the aquifer was drained and Phase 2 developed. The decrease in $U$ concentration in Phase 2 relative to 1 and 3 (Fig. 4) corroborates this, as it is the opposite of what is expected if $\mathrm{P}$ and $\mathrm{U}$ were related to higher infiltration and seasonal vegetation decay (Treble et al., 2003). It can be argued that, similarly to SC4, the source of P in the Winbirra samples was in the epikarst and in the host rock, rather than from soil-sourced chelates.

As the Early Pliocene drip water chemistry is unknown, we utilised a "speleothem enrichment factor" by comparing the concentration of trace elements in the host rock and in the speleothems. Although we are aware that the host rock composition is probably variable, that one cave is not representative of all sites, and that two speleothems are not representative of all the ca. $4 \mathrm{Myr}$ old stalagmites from the Nullarbor, we believe that our approach can be used to improve understanding of the trace element incorporation in these specimens from the deep past. In Fig. 6 the speleothem enrichment factors for 645-FS04 are visualised with respect to the different growth phases: Phase 2 is enriched in $\mathrm{P}, \mathrm{Al}, \mathrm{Si}$ and $\mathrm{Mg}$ relative to the host rock and in $\mathrm{Y}, \mathrm{Mn}, \mathrm{P}, \mathrm{Al}, \mathrm{Fe}$ and $\mathrm{Si}$ relative to phases 1 and 3 . By contrast, $\mathrm{U}$ in the columnar 

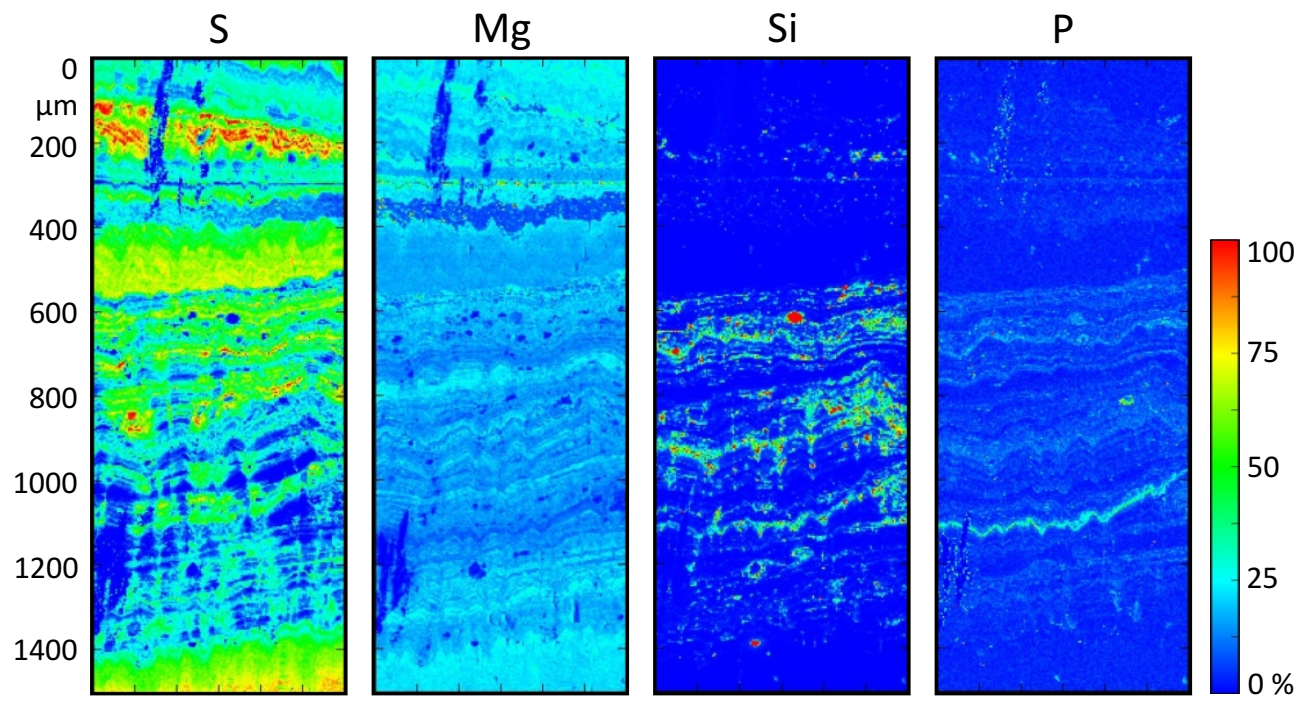

Fig. 5. Synchrotron radiation micro XRF maps for $\mathrm{S}, \mathrm{Mg}$, Si and $\mathrm{P}(600 \times 1500 \mu \mathrm{m}$, pixel size $2 \mu \mathrm{m})$ of the stromatolite-like layer in 645 FS04 illustrated in Fig. 4 (phase 2). Concentration distribution in temperature scale. All linear scales are normalized to the minimum and maximum counts for each element: $\mathrm{S}=0$ to 180 cts; $\mathrm{Mg}=0$ to $210 \mathrm{cts} ; \mathrm{Si}=0$ to $550 \mathrm{cts} ; \mathrm{P}=0$ to 35 cts. Sulphur is present as sulphate, and silicon is in amorphous silica form (see text for detailed discussion).

calcite has the same concentration as the host rock, but is depleted in Phase 2. One possible explanation is that Phase 2 is detritus-rich, which may be the case for a portion of $\mathrm{Si}$ as highlighted in the SR $\mu$ XRF map, but $\mathrm{P}$ is not detrital, because its distribution mimics crystal tips and laminae (Figs. 5 and 7). A portion of $\mathrm{Si}$ is also unlikely to be related to detritus, as its distribution follows the same micromorphology as $\mathrm{P}$, and Raman spectroscopy has revealed the presence of an amorphous silica phase. In analogy to what has been inferred from the dark layers of SC4 and on the basis of petrographic observations, the enrichment in trace elements relative to the host rock and the elongated, compact columnar calcite may be related to microbial processes. UV fluorescence associated with these laminae supports our hypothesis, which suggests the presence of organic compounds (Fig. S4). The implication is that the association of microbial laminae and amorphous silica indicates a lower drip rate relative to the columnar calcite, when microbial colonization of the speleothem surface was possible. The high concentration of sulphur as sulphate, confirmed by X-ray diffraction as being related to gypsum, particularly above the P-rich laminae in Phase 2, may be indicative of precipitation from evaporated waters.

At the tens of $\mu \mathrm{m}$-scale the SR $\mu$ XRF maps also show that $\mathrm{P}$ concentration is highest when $\mathrm{Mg}$ concentration is lowest (Fig. 5), which may be explained by the competition between $\mathrm{Mg}$ and $\mathrm{P}$ at kink sites, and/or the effect of Mg-reducing adsorption of phosphate (House and Donaldson, 1983; House et al., 1986).

Another analogy with $\mathrm{SC} 4$ is the presence of corrosion or dissolution, which is evident in the SR $\mu$ XRF maps of 645-MO1, where $\mathrm{P}, \mathrm{Si}$, and $\mathrm{S}$ as sulphate, as revealed by

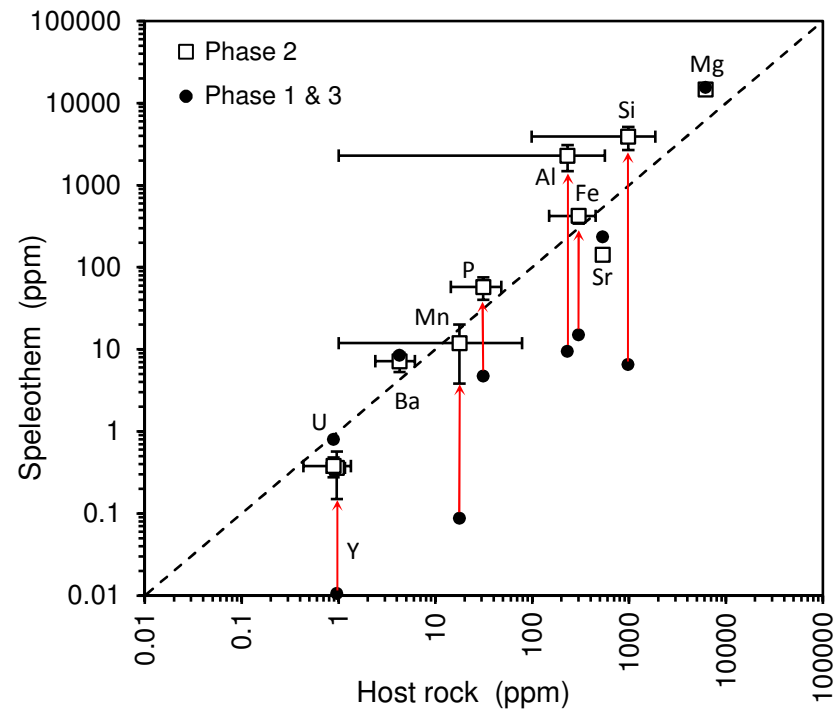

Fig. 6. Speleothem enrichment factor diagram constructed by comparing major and trace elements composition in the host rock and in speleothem 645-FS04. Chemical composition and growth phases correspond to those shown in Fig. 4. The red arrows highlight the elemental enrichment from average values in phases 1 and 3 with respect to phase 2. Error bars (1SD) are shown for phase 2 only.

XANES spectra, mark dissolutional surfaces and are associated with micrite (Fig. 7). It stands to reason, therefore, that the peaks in $\mathrm{P}$ associated with the stromatolite-like fabrics in the two Early Pliocene speleothems from Winbirra cave relate to periods of reduction (or cessation) of abiotic calcite growth, dissolution by microbial metabolism, 

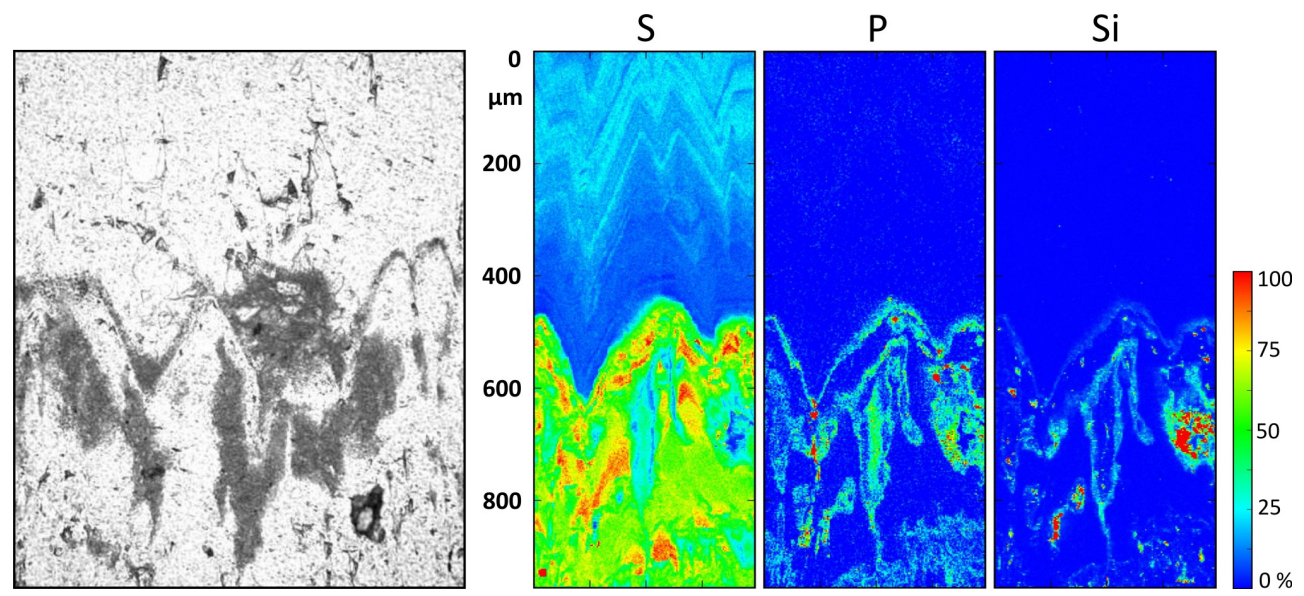

Fig. 7. Thin section and element map for the opaque, stromatolite-like layer in 645-MO1. Left: the thin section micrograph (same region of the synchrotron maps and same scale) shows micrite filling dissolution voids in the columnar crystals, as well as micrite filling the depressions between crystal terminations. Right: the Synchrotron radiation micro XRF maps $(400 \times 950 \mu \mathrm{m}$, pixel size $2 \mu \mathrm{m})$ for $\mathrm{S}$, P, and Si. Concentrations are given in a temperature scale. All linear scales are normalized to the minimum and maximum counts for each element: $\mathrm{S}=0$ to 240 cts; $\mathrm{P}=0$ to $32 \mathrm{cts} ; \mathrm{Si}=0$ to 195 cts. Note that $\mathrm{S}, \mathrm{P}$ and $\mathrm{Si}$ are all associated with micrite. See text for details.

and bacterially mediated calcite formation during progressive aquifer drainage. The time scale must be longer relative to the duration of the formation of the dark, irregular layers in $\mathrm{SC} 4$, but is presently not possible to quantify because of the $\mathrm{U} / \mathrm{Pb}$ dating uncertainties. Holocene analogues indicate that stromatolite-like layers may mark condensed sedimentation within a time period of about 200 to $2000 \mathrm{yr}$ (Frisia and Borsato, 2010). We can only speculate, then, that several tens of thousands of years of normal deposition of columnar calcite were interrupted by dry periods up to thousands of years in duration on the basis of the number of stromatolite-like layers and the mean age of the two samples.

The climate scenario reconstructed for the Early Pliocene is one of greater warmth and humidity compared to today, with an elevated water table in the caves due to higher sea levels, and a thick $\mathrm{C} 3$ vegetation cover at the surface (Stage 5 in Miller et al., 2012). The occurrence of stromatolite-like layers in two coastal cave speleothems suggests neither their formation under phreatic conditions because the morphology of the speleothems would be different, nor precipitation from seawater, which may have potentially inundated the cave, because aragonite would have formed (and there is no evidence of aragonite diagenesis in the two samples). In our interpretation, the stromatolite-like layers formed during dry spells, which may have interrupted the general humid conditions for a few centuries over several thousands of years. It is possible that climate instability in the region commenced at ca. $4 \mathrm{Myr}$, toward the end of the Zanclean, when the global sea level curve shifted to a low stand (Kominz et al., 1998). It has been argued that the gradual closure of the Central American Seaway (CAS), which reached a threshold in the Early Pliocene, had an influence on global climate by changing the dynamics of ocean and atmospheric circulation (cf. Steph et al., 2010).
In particular, Steph et al. (2010) concluded that the closure of CAS led to the development of the modern salinity contrast between Atlantic and Pacific, intensification of the Atlantic Meridional Overturning Circulation and an early start of the Eastern Equatorial Pacific cold tongue, thus a potential for $\mathrm{La}$ Niña conditions, at circa 4.3 and $4.0 \mathrm{Myr}$ ago. Thus, $\mathrm{P}$ concentration peaks associated with stromatolite-like layers may be a powerful proxy to unravel climate change in key periods of the deep past, when mean global surface temperatures were higher than today, atmospheric carbon dioxide concentrations were close to (or higher) than present-day values, but uncertainties in the palaeodata prevent a full understanding of climate mode transitions (cf. Brierley and Fedorov, 2010).

\section{Conclusions}

The palaeoclimatic significance of $\mathrm{P}$ concentration variability in speleothems is complex, because its pattern depends on the source, the calcium concentration in the drip water, the climate regime and the presence or absence of microbial activity. To date, the most important source of speleothem $P$ is believed to be seasonal vegetation dieback and $\mathrm{P}$ transport in chelated form to organic acids. Our study indicates that the main source of drip water P from our two host rock types may be leaching of phosphate minerals from the epikarst.

The incorporation of $\mathrm{P}$ in speleothems has been here shown to occur both via adsorption and incorporation of single ions into the crystal lattice, and via co-precipitation as discrete P-rich phases in discrete layers where biomediation may have played a role in both carbonate and phosphate formation. This undermines the concept of the thermodynamic partition coefficient $K_{\mathrm{P}}$, so we propose a new concept of a speleothem distribution coefficient for phosphorus 
$\left(\mathrm{SK}_{\mathrm{P}}\right)$, which accounts for all co-precipitated phases, regardless of the mechanisms of incorporation and their mineralogy. For ancient speleothems, where drip water data are not known, we suggest the use of a "speleothem enrichment factor" (SEF) as a proxy for $\mathrm{SK}_{\mathrm{P}}$.

The most important implication of this study for speleothem-based palaeoclimate reconstructions is that $\mathrm{P}$ variations in stalagmites may have a diverse climatic significance. In SC4, periods of high P concentration reflect low or negligible PCP following effective recharge of the aquifer in the rainy season. However, when P concentration peaks in dark, corroded layers, where phosphate-rich phases are possibly related to biomediation processes within pores, the palaeoclimatic significance may be different. These layers are interpreted as a response to piston effects caused by effective recharge following prolonged dry periods.

In two ca. 4 million year-old stalagmites from the Nullarbor, $\mathrm{P}$ concentration peaks are clearly associated with stromatolite-like layers. We suggest that microbial processes may have been involved in the $\mathrm{P}$ incorporation in the speleothems, and that the stromatolite-like layers mark periods of reduced drip rate and thus potentially indicative of dry phases of unknown duration within the otherwise wet climate regime of the Early Pliocene.

The implications of our study is that the use of P to refine palaeoclimate information from both recent and ancient speleothems should be underpinned by petrographic and elemental mapping to complement the usual laser-sourced time series to determine processes of trace element incorporation. Petrographic and chemical mapping should then become routine (cf. Fairchild and Baker, 2012), along with the chemical and textural characterization of the karst host rocks.

\section{Supplementary material related to this article is available online at: http://www.clim-past.net/8/2039/ 2012/cp-8-2039-2012-supplement.pdf.}

Acknowledgements. Nullarbor results were obtained within the framework of an ARC Discovery project (DP 0985214). We thank J. Woodhead for allowing us to use unpublished ages for the Nullarbor stalagmites. ESRF is acknowledged for provision of synchrotron radiation facilities. Vincent De Andrade and Murielle Salome assisted at ID21. S. Frisia and B. Paul are grateful to the Australian Synchrotron for the Grant AS_IA104_ESRF_EC794. Microscopy and XRD were carried out at the Electron Microscopy and X-ray Unit facility of the University of Newcastle. Maurizio Mattarelli helped with Raman spectroscopy at the University of Trento, Italy. Brian Phillips (SUNY at Stony Brook, USA) provided preliminary data on NMR analyses. Dr. Vanessa Johnston (Museo delle Scienze, Trento, Italy) helped processing synchrotron maps. We are deeply grateful to Mr. Mick Jeffery (Parks Australia North) for the drip water monitoring at Christmas Island and to the Australian Government - Bureau of Meteorology for the Christmas Island meteorological data. R. Drysdale gratefully acknowledges the University of Newcastle for providing a research project grant to launch the Christmas Island study. We would like to thank M. Luetscher and an anonymous reviewer for the excellent suggestions, which helped us improve the manuscript, and C. Spötl, who carefully edited the final version.

Edited by: C. Spötl

\section{References}

Addadi, L., Raz, S., and Weiner, S.: Taking advantge of disorder: amorphous calcium carbonate and its roles on biomineralization, Adv. Mat., 12, 959-970, 2003.

Alonso-Zarza, A. M. and Wright, V. P.: Calcretes, in: Carbonates in Continental Settings, edited by: Alonso-Zarza, A. M. and Tanner, L. H., Developments in Sedimentology, Elsevier, Amsterdam, 269-318, 2010.

Ayliffe, L. K., Veeh, H. H., and Chivas, A.: Oxygen isotopes of phosphate and the origin of Island apatite deposits, Earth Planet. Sci. Lett., 108, 119-129, 1992.

Banfield, J. F. and Nealson, K. H. (Eds.): Geomicrobiology: Interactions Between Microbes and Minerals, Mineralogical Society of America Reviews in Mineralogy, 35, 448 pp., 1997.

Barton, H. A. and Northrup, D. E.: Geomicrobiology in cave environments: past, current and future perspectives, J. Cave Karst Stud., 69, 163-178, 2007.

Blyth, A. J. and Frisia, S.: Molecular evidence for bacterial mediation of calcite formation in cold high-altitude caves, Geomicrobiol. J., 25, 101-111, 2008.

Borsato, A., Frisia, S., Jones, B., and van der Borg, K.: Calcite moonmilk: crystal morphology and environment of formation in caves in the Italian Alps, J. Sediment. Res., 70, 1179-1190, 2000.

Borsato, A., Frisia, S., Fairchild, I. J., Somogyi, A., and Susini, J.: Trace element distribution in annual stalagmite laminae mapped by micrometer-resolution X-ray fluorescence: implications for incorporation of environmentally significant species, Geochim. Cosmochim. Ac., 71, 1494-1512, 2007.

Braissant, O., Cailleau, G., Dupraz, C. M., and Verrecchia, E.: Bacterially induced mineralization of calcium carbonate in terrestrial environments: The role of expolysaccharides and amino acids, J. Sediment. Res., 73, 485-490, 2003.

Brierley, C. M. and Fedorov, A. V.: Relative importance of meridional and zonal sea surface temperature gradients for the onset of the ice ages and Pliocene-Pleistocene climate evolution, Paleoceanography, 25, 1-16, 2010.

Cacchio, P., Contento, R., Ercole, C., Cappuchio, G., Martinez, M. P., and Lepidi, A.: Involvement of microorganisms in the formation of carbonate speleothems in the Cervo Cave (L'AquilaItaly), Geomicrobiol. J., 21, 497-509, 2004.

Cañaveras, J. C., Sanchez-Moral, S., Soler, V., and Saiz-Jimenez, C.: Microbial communities associated with hydromagnesite and needle fiber aragonite deposits in a karstic cave (Altamira, Northern Spain), Geomicrobiol. J., 12, 9-25, 1999.

Castanier, S., Le Metayer-Levrel, G., and Perthuisot, J.-P.: Bacterial roles in the precipitation of carbonate minerals, in: Microbial Sediments, edited by: Riding, R. E. and Awramik, S. M., Springer-Verlag, Heidelberg, 32-39, 2000.

Combes, C. and Rey, C.: Adsorption of proteins on calcium phosphate materials bioactivity, Biomaterials, 23, 2817-2823, 2002. 
Dreybrodt, W. and Scholz, D.: Climatic dependence of stable carbon and oxygen isotope signals recorded in speleothems: from soil water to speleothem calcite, Geochim. Cosmochim. Ac., 75, 734-752, 2011.

Fairchild, I. J. and Baker, A.: Speleothem Science: From Process to Past Environment, Wiley-Blackwell, 450 pp., 2012.

Fairchild, I. J., Baker, A., Borsato, A., Frisia, S., Hinton, R. W., McDermott, F., and Tooth, A. F.: Annual to sub-annual resolution of multiple trace-element trends in speleothems, J. Geol. Soc., 158, 831-841, 2001.

Fairchild, I. J., Spötl, C., Frisia, S., Borsato, A., Susini, J., Wynn, P. M., Cauzid, J., and EIMF: Petrology and geochemistry of annually laminated stalagmites from an Alpine cave (Obir, Austria): seasonal cave physiology, in: Tufas and speleothems: unravelling the microbial and physical controls, edited by: Pedley, H. M. and Rogerson, M., Geological Society, London, Special Publications, 336, 295-321, 2010.

Filippelli, G. M.: The Global Phosphorous Cycle in: Phosphates - Geochemical, Geobiological and Materials Importance, edited by: Kohn, M. J., Rakovan, J., and Huges, J. M., Mineralogical Society of America Reviews in Mineralogy and Geochemistry, 48, 391-425, 2002.

Frisia, S.: Petrographic evidence for diagenesis in speleothems: Some examples, Speleochronos, 7, 21-30, 1996.

Frisia, S. and Borsato, A.: Karst, in: Carbonates in Continental Settings, edited by: Alonso-Zarza, A. M. and Tanner, L. H., Developments in Sedimentology, Elsevier, Amsterdam, 269-318, 2010.

Frisia, S., Borsato, A., Fairchild, I. J., and McDermott, F.: Calcite fabrics, growth mechanisms, and environments of formation in speleothems from the Italian Alps and South-western Ireland, J. Sediment. Res., 70, 1183-1196, 2000.

Frisia, S., Borsato, A., Fairchild, I. J., and Susini, J.: Variations in atmospheric sulphate recorded in stalagmites by synchrotron micro-XRF and XANES analyses, Earth Planet. Sci. Lett., 235, 729-740, 2005.

Grimes, K. G.: Karst features of Christmas Island (Indian Ocean), Helictite, 37, 41-58, 2001.

Griffiths, M. L., Drysdale, R. N., Gagan, M. K., Frisia, S., Zhao, J.X., Ayliffe, L. K. Hantoro, W. S., Fischer, M. J., Feng, Y.-X., and Suwargadi, B. W.: Evidence for Holocene changes in AustralianIndonesian monsoon rainfall from stalagmite trace elements and stable isotope ratios, Earth Planet. Sci. Lett., 292, 27-38, 2010.

Hartland, H., Fairchild, I. J, Lead, J. R., Borsato, A., Baker, A., Frisia, S., and Baalousha, M.: From soil to cave: Transport of trace metals by natural organic matter in cave dripwaters, Chem. Geol., 304-305, 68-82, 2012.

Hendy, C. H.: The isotopic geochemistry of speleothems - I. The calculation of the effects of different modes of formation on the isotopic composition of speleothems and their applicability as paleoclimatic indicators, Geochim. Cosmochim. Ac., 35, 801824, 1971.

Hellstrom, J. C. and McCulloch, M. T.: Multi-proxy constraints on the climatic significance of trace element records from a New Zealand speleothem, Earth Planet. Sci. Lett., 179, 287-297, 2000.

House, W. A. and Donaldson, L.: Adsorption and coprecipitation of phosphate in calcite, J. Colloid Interf. Sci., 112, 309-324, 1983.
House, W. A., Casey, H., Donaldson, L., and Smith, S.: Factors affecting the coprecipitation of inorganic phosphate with calcite in hardwaters. I - Laboratory Studies, Water Resour., 20, 917-922, 1986.

Hu, C., Huang, J., Fang, N., Xie, S., Henderson, G., and Cai, Y.: Adsorbed silica in stalagmite carbonate and its relationship to past rainfall, Geochim. Cosmochim. Ac., 69, 2285-2292, 2005.

Hua, Q., McDonald, J., Redwood, D., Drysdale, R., Lee, S, Fallon, S., and Hellstrom, J.: Robust chronological reconstruction for young speleothems using radiocarbon, Quaternary Geochronol., doi:10.1016/j.quageo.2012.04.017, in press, 2012.

Huang, Y., Fairchild, I. J., Borsato, A., Frisia, S., Cassidy, N. J., McDermott, F., and Hawkesworth, C. J.: Seasonal variations in $\mathrm{Sr}, \mathrm{Mg}$ and $\mathrm{P}$ in modern speleothems (Grotta di Ernesto, Italy), Chem. Geol., 175, 429-448, 2001.

Ishikawa, M. and Ichikuni, M.: Coprecipitation of phosphate with calcite, Chem. J., 15, 283-288, 1981.

James, J. M.: Corrosion par melange des eaux dans les grottes de la Plaine de Nullarbor, Australia, in: Karst et Evolutions Climatique, edited by: Salomon, J.-N. and Maire, R., Presses Universitaires de Bordeaux, Bordeaux, 333-348, 1992.

Jones, B.: Microbial activity in caves - a geological perspective, Geomicrobiol. J., 18, 1-13, 2001.

Jones, B.: Phosphatic precipitates associated with actinomycetes in speleothems from Grand Cayman, British West Indies, Sediment. Geol., 219, 302-317, 2009.

Jones, B.: The preferential association of dolomite with microbes in stalactites from Cayman Brac, British West Indies, Sediment. Geol., 226, 94-19, 2010a.

Jones, B.: Speleothems in a wave-cut notch, Cayman Brac, British West Indies: the integrated product of subaerial precipitation, dissolution, and microbes, Sediment. Geol., 232, 15-34, 2010 b.

Kominz, M. A., Miller, K. G., and Browning, J. V.: Long-term and short-term global Cenozoic sea-level estimates, Geology, 26, 311-314, 1998

Lewis, S. C., Gagan, M. K. Ayliffe, L. K., Zhao, J.-X., Hantoro, W. S., Treble, P. C., Hellstrom, J., La Grande, A., Kelley, M., Schmidt, G. A., and Suwargadi, B. W.: High-resolution stalagmite reconstructions of Australian-Indonesian monsoon rainfall variability during Heinrich stadial 3 and Greenland interstadial 4, Earth Planet. Sci. Lett., 303, 133-142, 2011.

Mason, H. E., Frisia, S., Tang, Y., Reeder, R. J., and Phillips, B.: Phosphorus speciation in calcite speleothems determined from solid-state NMR spectroscopy, Earth Planet. Sci. Lett., 254, 313322, 2007.

Miller, C. R., James, N. P., and Bone, Y.: Prolonged carbonate diagenesis under an evolving late Cenozoic climate; Nullarbor Plain, southern Australia, Sediment. Geol., 261-262, 33-49, 2012.

Miorandi, R., Borsato, A., Frisia, S., Fairchild, I. J., and Richter, D. K.: Epikarst hydrology and implications for stalagmite capture of climate changes at Grotta di Ernesto (NE Italy): results from long-term monitoring, Hydrol. Process., 24, 3101-3114, 2010.

Morse, J. W., Gledhill, D. K., and Millero, F. J.: $\mathrm{CaCO}_{3}$ precipitation kinetics in waters from the Great Bahama Bank: Implications for the relationship between Bank hydrochemistry and whitings precipitation kinetics in waters from the Great Bahama Bank: Implications for the relationship between Bank hydrochemistry and whitings, Geochim. Cosmochim. Ac., 67, 
2819-2826, 2003.

Nash, D. J. and Ullyott, J. S.: Silcrete, in: Geochemical Sediments and Landscapes, edited by: Nah, D. J. and McLaren, S., Blackwell Publishing, 95-143, 2007.

Paton, C., Hellstrom, J., Paul, B., Woodhead, J., and Hergt, J.: Iolite: Freeware for the visualisation and processing of mass spectrometric data, J. Anal. Atom. Spectrom., 26, 2508-2518, 2011.

Polyak, V. J. and Güven, N.: Authigenesis of trioctaehedral smectite in magnesium-rich carbonate speleothems in Carlsbad Cavern and other caves of the Guadalupe Mountains, New Mexico, Clay. Clay Miner., 48, 317-321, 2000.

Prior, L. D. and Eamus, D.: Seasonal changes in hydraulic conductance, xylem embolism and leaf area in Eucalyptus tetrodonta and Eucalyptus miniata saplings in a north Australian savanna, Plant Cell Environ., 23, 955-965, 2000.

Redwood, D. A., Drysdale, R. N., Goodwin, I. D., McDonald, J., Hellstrom, J. C., Hodge, E., and Jeffery, M.: The use of geochemical properties as climate indicators from a Christmas Island (Indian Ocean) stalagmite, Geophys. Res. Abstracts, 9, SRefID:1607-7962/gra/EGU2007-A-05921, 2007.

Romanek, C. S., Grossmann, E. L., and Morse, J. W.: Carbon isotopic fractionation in synthetic aragonite and calcite: Effects of temperature and precipitation rate, Geochim. Cosmochim. Ac., 56, 419-430, 1992.

Rossi, C., Lozano, R. P., Isanta, N., and Hellstrom, J.: Manganese stromatolites in caves: El Soplao (Cantabria, Spain), Geology, 38, 1119-1122, 2010.

Sánchez-Román, M., Rivadeneyra, M. A., Vasconcelos, C., and McKenzie, J. A.: Biomineralization of carbonate and phosphate by moderately halophilic bacteria, FEMS Microbiology Ecology, 61, 273-284, 2007.

Scholz, D., Mühlinghaus, C., and Mangini, A.: Modelling $\delta^{13} \mathrm{C}$ and $\delta^{18} \mathrm{O}$ in the solution layer on stalagmite surfaces, Geochim. Cosmochim. Ac., 73, 2592-2602, 2009.

Sø, H. U., Postma, D., Jakobsen, R., and Larsen, F.: Sorption of phosphate onto calcite; results from batch experiments and surface complexation modeling, Geochim. Cosmochim. Ac., 75, 2911-2923, 2011.
Steph, S., Tiedemann, R., Prange, M., Groeneveld, J., Schulz, M., Timmermann, A., Nurnberg, D., Ruhlemann, C., Saukel, C., and Haug, G. H.: Early Pliocene increase in thermohaline overturning: A precondition for the development of the northern equatorial Pacific cold tongue, Paleoceanography, 25, 1-17, 2010.

Stoll, H. M., Müller, W., and Prieto, M.: I-STAL, a model for interpretation of $\mathrm{Mg} / \mathrm{Ca}, \mathrm{Sr} / \mathrm{Ca}$ and $\mathrm{Ba} / \mathrm{Ca}$ variations in speleothems and its forward and inverse application on seasonal to millennial scales, Geochem. Geophys. Geosys., 13, Q09004, doi:10.1029/2012GC004183, 2012.

Treble, P., Shelley, J. M. G., and Chappell, J.: Comparison of high resolution sub-annual records of trace elements in a modern (1911-1992) speleothem with instrumental climate data from southwest Australia, Earth Planet. Sci. Lett., 216, 141-153, 2003.

Tremaine, D. M., Froelich, P. N., and Wang, Y.: Speleothem calcite farmed in situ: Modern calibration of $\delta^{18} \mathrm{O}$ and $\delta^{13} \mathrm{C}$ palaeoclimate proxies in a continuously-monitored natural cave system, Geochim. Cosmochim. Ac., 75, 4929-4950, 2011.

Trueman, N. A.: The phosphate, volcanic and carbonate rocks of Christmas Island (Indian Ocean), J. Geol. Soc. Aust., 12, 261283, 1965

Turin, H. J. and Webb, J. A.: Groundwater geochemistry and isotopes near Mullamullang Cave, Nullarbor Plain, Western Australia, Geological Society of America Annual Meeting, Denver, Colorado, Abstract, 218-23, 2002.

Van Leerdam, D. M., Williams, P. A., and Cairney, J. W. G.: Phosphate - solubilising abilities of ericoid mycorrhizal endophytes of Woollsia pungens (Epacridaceae), Australian, J. Botany, 49, 75-80, 2001.

Warren, L. A., Maurice, P. A., Parmar, N., and Ferris, F. G.: Microbially Mediated Calcium Carbonate Precipitation: Implications for Interpreting Calcite Precipitation and for Solid-Phase Capture of Inorganic Contaminants, Geomicrobiol. J., 18, 93-115, 2001.

Woodhead, J., Hellstrom, J., Maas, R., Drysdale, R., Zanchetta, G., Devine, P., and Taylor, E.: U-Pb geochronology of speleothems by MC-ICPMS, Quaternary Geochronol., 1, 208-221, 2006. 